\title{
IN MEMORIAM: STEPHEN MANN (1895-1968)
}

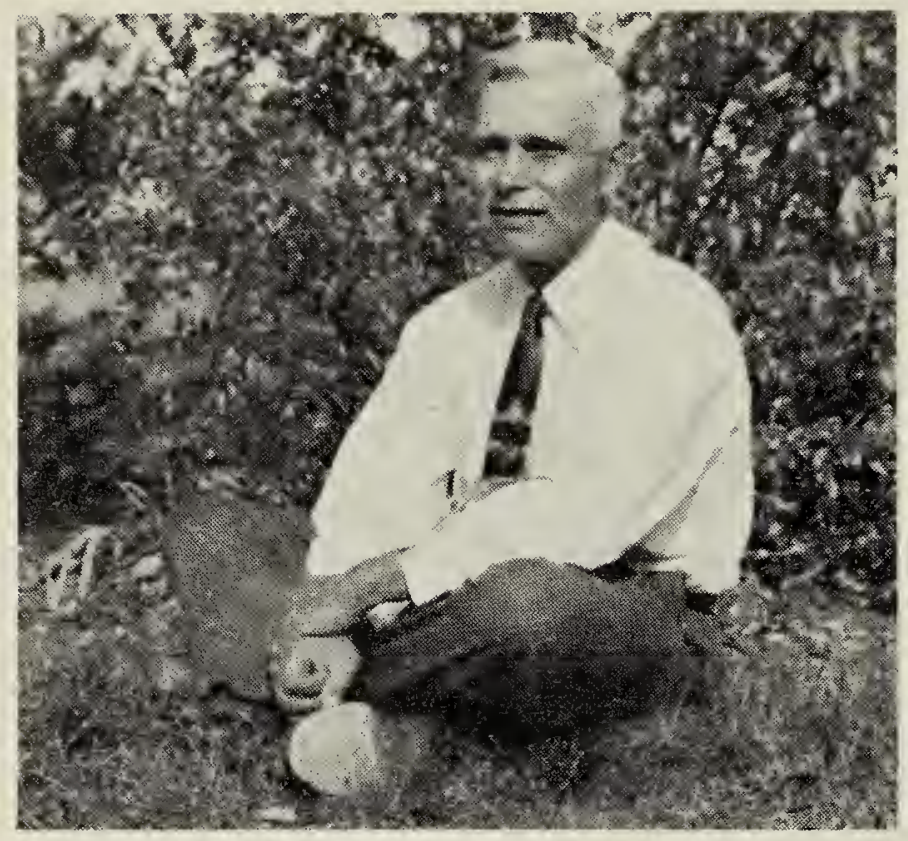

Steve Mann was born in the ranching country at Skull Creek in 1895, and died there in August, 1968. Over the years, when the Mann home was a kind of crossroads for the community, Steve Mann became known for the open heart and mind that characterize the people of the High Plains.

Steve Mann was beloved by his own Skull Creek community and by the wide circle of friends in the Saskatchewan Natural History Society with whom he shared his love of the outdoors and his observations of nature. At the suggestion of the Mann family, the Reverend G. E. Smith has sent us for publication the tribute he paid Mr. Mann at the funeral service.

\section{An Appreciation}

As a boy Stephen Mann was usually on hand with members of the family to welcome the Anglican priest on his annual visit to the ranch. In the early part of this century the clergyman rode on horseback, calling in at many ranches and farms between Medicine Hat and Fort Qu'Appelle. There were baptisms and marriages and many an earnest conversation during those sojourns. He told me about the services in that old log house which later became the oldest active post office in Saskatchewan. In fine weather the family and their neighbours might take part in an outdoor service on the grass close to the house. A small organ was used.

The active interest in the Christian Church continued throughout the life of Stephen Mann. The ranch was sometimes visited by the scarlet- jacketed men of The North-West Mounted Police as they rode across the Skull Creek country to and from Maple Creek. At first, the nearest religious services were in the small church at Piapot, which was visited by the family when weather was fine and transportation available. Some years later services began at Mannville Schoolhouse, close to the ranch, Mannville becoming a part of the Maple Creek and Gull Lake parishes. These services were continued until August, 1968. Steve Mann was rarely ever absent from church and he served for some years as Warden and Treasurer of his congregation. I sometimes referred to him affectionately as the "head man"!

In order to appreciate the very full life and witness of this dear man one ought to think of him in the light of that part of Saint Matthew's Gospel recorded in Chapter 6:24-34. These lines help us to comprehend something of the beautiful simplicity of his life on the prairie. Many of his old friends within The Saskatchewan Natural History Society have seen how deeply he loved people, and all the creatures of God's Creation.

"Look at the birds of the air; they do not sow and reap and store in barnis, yet our heavenly Father feeds them.

"Consider how the lilies grow in the fields; they do not work, they do not spin; and yet, I tell you, even Solomon in all his splendour was not attired like one of these."

His was from the early years a life closely influenced by the Good Shepherd. Stephen believed that for the Christian, death is not a tragedy, but a triumphant entrance into a fuller life. As the members of his family and his friends continue to lend their wholehearted support to this Society, they will surely remember with very great joy this lover of God.-The Reverend G. E. Smith, Hodgeville, Saskatchewan. 